\title{
A QUANTITATIVE AUTOMATED TECHNIQUE FOR THE DETERMINATION OF DIAZOTIZABLE IMIDAZOLE COMPOUNDS IN BIOLOGICAL MATERIAL
}

WALTEIR D. BLOCK, RICIARD W. HUBBARD* AND MARY H. WESTHOFF

Department of Dermatology, Biochemical Research Laboratories, University of Michigan, Medical Center, Ann Arbor, Mich. (U.S.A.)

(Received November I5th, I965)

\section{INTRODUCTION}

Methods used to determine the metabolism of imidazole compounds in biological materials range from the use of enzymes to ion-exchange chromatography ${ }^{1-5}$.

To facilitate studies in which a number of biological samples may be analyzed in a relatively short time for a series of imidazole compounds in which the $I, 2$, and 3 positions on the ring are "non-substituted", a quantitative, automated method has been developed combining ion-exchange chromatography and the modified PAULY reaction ${ }^{6}$. An extract of the biological material is applied to a column containing resin, and a buffer gradient of increasing $\mathrm{pH}$ and ionic strength is applied to separate the imidazole compounds. The resulting eluate automatically is made alkaline, diazotized, and the color produced is determined by continuous photometry. The results are plotted automatically on a recording microammeter.

\section{MATERIALS AND METHODS}

\section{Apparatils}

Chromatographic tubes and resin. A heavy walled, jacketed chromatograph tube, $0.9 \mathrm{~cm}$ in diameter and $106 \mathrm{~cm}$ in length from the Teflon plate to the top of the tube is used. An I8/9 socket joint is attached to the top of the tube, and a I2/5 glass ball joint is affixed at the bottom. The column jacket is maintained at $50^{\circ}$ throughout the 18 to $20 \mathrm{~h}$ of the chromatographic period by the circulating fluid system used by SPACKMAN et al.?.

The column is filled to a height of $85-90 \mathrm{~cm}$ with $24-32$ micron beads of unground $8 \%$ cross-linked, sulfonated polystyrene resin, sodium form (Chromo-bead resin, Type A, Technicon Instruments Corp., Chauncey, N.Y.). The resin is prepared and poured in the manner described for the preparation of columns for amino acid analysis by MOORE et al. ${ }^{8}$, except that a citrate buffer, $\mathrm{pH} 3.90$, is used (Table I, buffer I). Before use, the resin column is regenerated by pumping through it $\mathrm{CO}_{2}$-free $\mathrm{NaOH}, 0.2 M\left(\mathrm{Na}^{+}\right)$, followed by buffer I (Table I).

- Present address: IResearch Department, Beckman Instruments, Inc., Spinco Division, I I 7 Californin Avenue, Palo Alto, California. 
TABLE I

BUFPER GRADIENT

Buffer I, pH $3.90 \pm 0.02,0.20 \mathrm{M}\left(\mathrm{Na}^{+}\right)$containing: $189.8 \mathrm{r}$ g citric acid $\cdot \mathrm{H}_{2} \mathrm{O} ; 74.25 \mathrm{~g} \mathrm{NaOH}$ $(97 \%) ; 58.50 \mathrm{ml} \mathrm{H}-1 \mathrm{Cl} ; 0.90 \mathrm{ml}$ caprylic acid; diluted to 91 . Before use $2 \mathrm{ml} / \mathrm{l}$ of $\mathrm{Brij}-35$ (50 $\mathrm{g}$ per IOO $\mathrm{ml}$ of $\mathrm{H}_{2} \mathrm{O}$ ) is added. Buffer IJ, $\mathrm{PH} 6.25 \pm 0.02,0.33 \mathrm{M}\left(\mathrm{Na}^{+}\right)$containing: 29I.I $5 \mathrm{~g}$ sodium citrate. $2 \mathrm{H}_{2} \mathrm{O} ; 0.45 \mathrm{~g}$ ethylenediaminetetraacetic acid; I0.80 $\mathrm{ml} \mathrm{HCl} ; 0.90 \mathrm{ml}$ caprylic acid; diluted to $9 \mathrm{l}$. Before use $2 \mathrm{ml}$ per liter of $\mathrm{Brij}-35\left(5 \circ \mathrm{g}\right.$ per $100 \mathrm{ml}$ of $\left.\mathrm{H}_{2} \mathrm{O}\right)$ is added.

\begin{tabular}{llc}
\hline $\begin{array}{l}\text { Chamber } \\
\text { number }\end{array}$ & \multicolumn{2}{l}{$\begin{array}{l}\text { Amount of buffer } \\
(\mathrm{ml})\end{array}$} \\
\cline { 2 - 3 } & $I$ & $I I$ \\
\hline $\mathrm{I}$ & 67 & 0 \\
2 & 55 & 12 \\
3 & 43 & 24 \\
4 & $3 \mathrm{I}$ & 36 \\
5 & 20 & 47 \\
6 & 8 & 59 \\
7 & 0 & 67 \\
8 & 0 & 67 \\
9 & 0 & 67 \\
\hline
\end{tabular}

Buffer gradient. A 9-chambered "Block Autograd" (Technicon Instruments Corp.) supplies a continuous flow of variable buffer gradient. The quantities and composition of the buffers used in each chamber are shown in Table I. The outlet of the variable gradient device is connected by Tygon tubing, 3/I 6 in. I.D., to a I2/5 ballsocket joint. The socket section is joined by glass tubing, I/I6 in. I.D., to a series of 2 Teflon, 3-way stopcocks (size no. 2) united by Tygon tubing. One outlet of the first 3-way stopcock permits the buffer gradient to flow to the second stopcock; the other outlet is attached by glass tubing $\mathrm{I} / \mathrm{I} 6$ in. I.D., to a reservoir containing buffer I, (Table I). The second 3-way stopcock has one inlet attached by Tygon tubing, I/I 6 in. I.D., to a reservoir containing $0.2 \mathrm{M}\left(\mathrm{Na}^{+}\right), \mathrm{CO}_{2}$-free $\mathrm{NaOH}$; the outlet connects with Tygon tubing, I/I6 in. I.D., to a T-bore Teflon stopcock (size no. 2), one end of which is left free to permit the operator to release air bubbles trapped in the system. The other end is connected with Tygon tubing, I/I6 in. I.D., to a Milton Roy CHMML-B-X chromatographic minipump with column valve liquid ends (Beckman Instruments, Inc., Palo Alto, Calif.) which pumps the buffer through a FP I/I6-IO-G-5/8I, Fischer and Porter, Warminster, Penn., flow-meter; and thence through Tygon tubing, I/I6 in. I.D., fitted with a U.S. $3^{823}$ by-pass pressure gauge (U.S. Gauge Co., Sellersville, Penn.), to an IS $\mathrm{mm}$ ball with a swivel fitting (Beckman Instruments, Inc.) which is accommodated by the socket on top of the chromatographic column.

Analysis of column effluent. The column effluent is fed through a Beckman Instruments, Inc., 5/I2 ball acceptor with a swivel fitting (attached with spring clips to the glass ball at the bottom of the column) and Teflon tubing, I/32 in. I.D., into one capillary arm of a G-2 standard cactus*. Air is pumped through the second capillary arm of the cactus (Double Red Tygon tubing*) and $\mathrm{Na}_{2} \mathrm{CO}_{3}$ through the standard arm (Double Green Tygon tubing*) by a proportioning pump*, and are mixed with the effluent in a standard length mixing coil (Fig. I). Sulfanilic acid is

* Technicon Instruments Corp. 


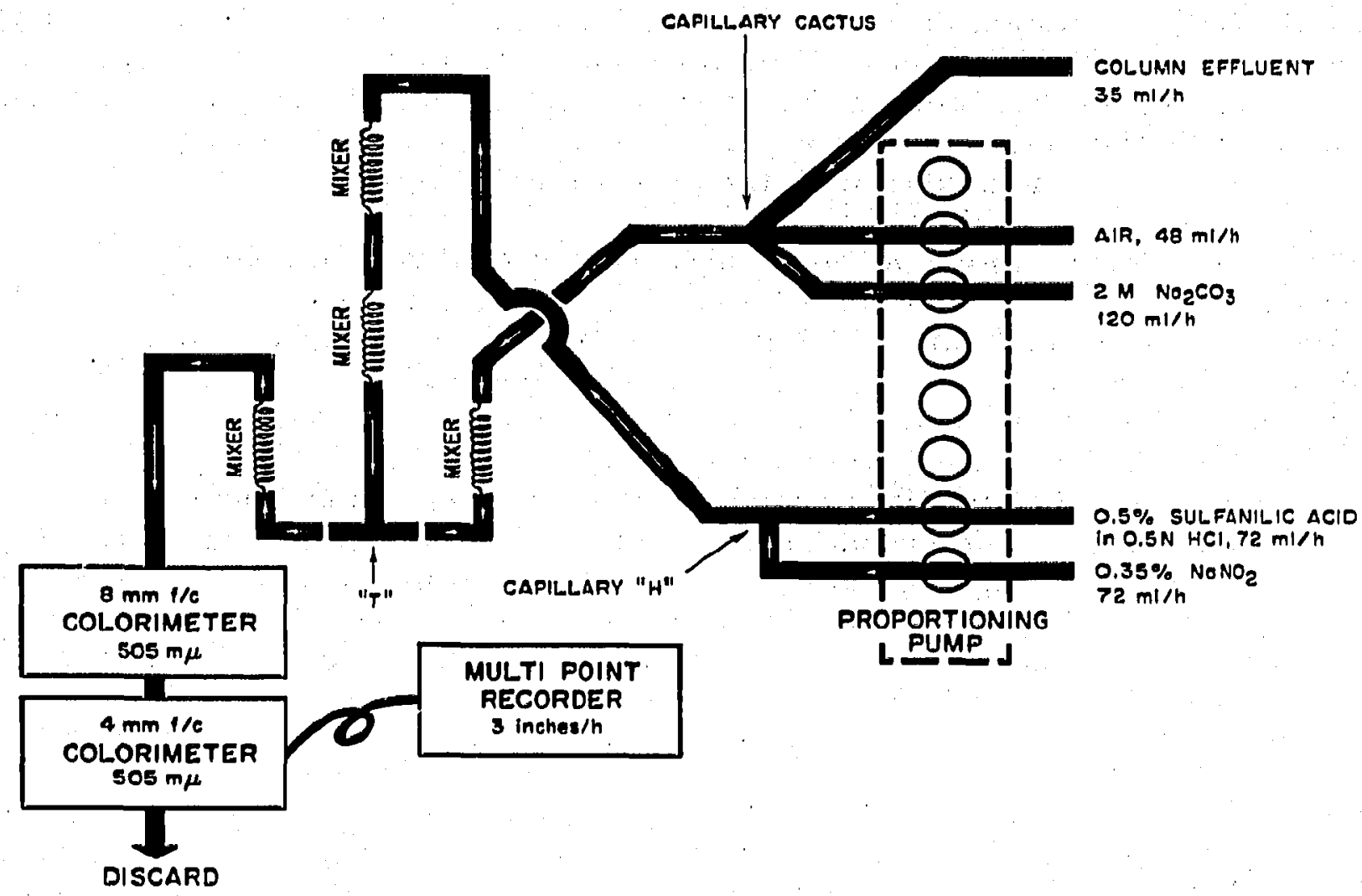

Fig. I. Schema for automated diazotization of column effuent and recording of optical density produced. The abbreviation " $f / c$ " denotes flow-cell.

pumped through the standard arm and $\mathrm{NaNO}_{2}$ through the capillary arm of a D-I "H"-tube" (Double Yellow Tygon tubing") by the proportioning pump and are mixed together as they flow through 2 standard length mixing coils". The alkaline effuent and the diazotizing mixture enter a standard length mixing coil ${ }^{*}$ at room temperature (Fig. r). The diazotized effluent proceeds directly into a pair of flow colorimeters" equipped with $8 \mathrm{~mm}$ and $4 \mathrm{~mm}$ cuvettes with wavelength filters of $505 \mathrm{~m} \mu$. The colorimeter signals are recorded into a multiple-point (three) Bristol recorcler * with a chart speed of 3 in./h (Fig. I). One of the 3 channels is "damped-out" to give a baseline.

Addition of sample to colnmn. A solution of the sample to be analyzed is pipetted onto the top of the column and driven into the resin with air, I5 p.s.i. The sample is washed in with three $0.5-0.7 \mathrm{ml}$ aliquots of buffer I (Table I). The ball joint from the buffer gradient system is attached, the pump started, and the buffer gradient allowed to flow through the chromatographic column for I8 to $20 \mathrm{~h}$.

Regenevation of the colncmn. The ion-exchange chromatographic column is regenerated whenever the resin is replaced, or a sample has been chromatographed. Regeneration is begun by disconnecting the "Block Autograd" at the I2/5 joint, and using a syringe to rinse the glass section between the joint and the first Teflon 3-way stopcock with buffer I (Table I). The second Teflon 3-way stopcock referred to under Buffer gradient is turned so the $\mathrm{CO}_{2}$-free $0.2 M\left(\mathrm{Na}^{+}\right)$NaOHI from the reservoir is

Technicon Instruments Corp. 
pumped through the system at a rate of $30 \mathrm{ml} / \mathrm{h}$ for 20 to $30 \mathrm{~min}$. The stopcock is then turned to a position to receive solution through the outlet of the first stopcock, which is positioned so that buffer I (Table I) is pumped from the reservoir through the column until the eluate attains a $\mathrm{pH}$ of 3.90 . The procedure usually requires about $3.5 \mathrm{ll}$. The Autogracl is filled with the proper buffers, reconnected, and the system is ready for another analysis.

Standard mixture of imidazole compounds. The apparatus is stanclardized by the use of a mixture of synthetic imidazole compounds, each of which was found in individual studies to be recoverable in a single peak from the ion-exchange column.

A stock solution is made by weighing I25 $\mu$ moles each of the following compounds: imidazolepyruvic acid ${ }^{*}$, imidazolelactic acid ** L-tyrosine, L-histidine and L-carnosine obtained from Nutritional Biochemicals Corp., Cleveland, Ohio; imidazoleacetic acid $\cdot \mathrm{HCl}$, dihydrourocanic acid (imidazolepropionic acid), urocanic acid $\cdot \mathrm{H}_{2} \mathrm{O}$, and 4-amino-5-imidazolecarboxamide $\cdot \mathrm{HCl}$ from California Corp. for Biochem. Research, Los Angeles, Calif.; and L-homocarnosine obtained from Regis Chem. Co., Chicago, Ill. The compounds are placed into an $100 \mathrm{ml}$ volumetric flask and $5 \mathrm{ml}$ of $6 \mathrm{M} \mathrm{HCl}$ added. As some of them dissolve with difficulty, the mixture is heated slightly by placing the flask in hot water until solution is achieved. The solution is cooled, brought to volume, and stored in $5 \mathrm{ml}$ amounts in ampules under $\mathrm{N}_{2}$ at $-20^{\circ}$.

Various concentrations of the stock solution which are applied to the column are obtained by diluting the solution with appropriate amounts of citrate buffer, $\mathrm{pH} 2.2 \pm 0.03$, prepared from the following: $2 \mathrm{I} .0 \mathrm{~g}$ citric acid $\cdot \mathrm{H}_{2} \mathrm{O}, 8.3 \mathrm{~g} \mathrm{NaOH}$ $(97 \%), 16.0 \mathrm{ml} \mathrm{HCl}$, o.I $\mathrm{ml}$ caprylic acid, $20.0 \mathrm{ml}$ thiodiglycol, and diluted to I liter with water ${ }^{11}$.

TABLE II

CONSTANTS FOR VARIOUS IMIDAZOLE COMPOUNDS AND TYROSINE

\begin{tabular}{|c|c|c|c|c|c|c|}
\hline \multirow[t]{2}{*}{ Compound } & \multicolumn{4}{|c|}{ Concentration ( $\mu$ moles) } & \multirow{2}{*}{$\begin{array}{l}\text { Average } \\
\text { constant }\end{array}$} & \multirow{2}{*}{$\begin{array}{l}\text { Maximum de } \\
\text { viation from } \\
\text { mean }(\%)\end{array}$} \\
\hline & 0.125 & 0.250 & 0.500 & $x .000$ & & \\
\hline Imiclazolepyruvic acid & 2.20 & & 2.20 & & 2.20 & 0.0 \\
\hline Imiclazolelactic acicl & 15.76 & 15.96 & I6.20 & & 15.97 & $\mathrm{r.4}$ \\
\hline Tyrosine & 5.68 & 5.00 & 4.54 & & 5.07 & 12.0 \\
\hline Imidazoleacetic acid & 19.92 & 20.08 & 20.24 & $20.4 I$ & 20.16 & 1.2 \\
\hline $\begin{array}{l}\text { Urocanic acid } \\
\text { Dihydrourocanic acid }\end{array}$ & 14.80 & $I_{4} \cdot 6_{4}$ & I. 4.98 & $I_{4} .97$ & 14.85 & 0.9 \\
\hline (imiclazolepropionic acicl) & 19.04 & 18.80 & $18.5^{6}$ & 19.02 & I8.86 & I. 5 \\
\hline 4-Amino-5-imidazole carboxamide & & 1.76 & $\begin{array}{r}1.82 \\
.0 .86\end{array}$ & 1.88 & 1.82 & $3 \cdot 3$ \\
\hline Histidine & I9.1.2 & 18.72 & I 8.96 & 19.58 & 19.10 & 2.5 \\
\hline Itomocarnosine & 12.00 & 12.16 & 11.86 & $12 . x_{4}$ & 12.04 & 1.4 \\
\hline Carnosine & I3.12 & $\mathrm{r}_{3} .80$ & 13.50 & 13.66 & 13.67 & 4.0 \\
\hline
\end{tabular}

The constants for each imidazole compound are computed in the same manner as the constants for amino acid analysis as given by SpAcirmaN et al. ${ }^{7}$, and are given in Table II for the apparatus used in this laboratory. Each laboratory will, of course,

" Prepared by the methods of Spolter AND BALdridge ${ }^{0}$ and BAIDRIDGe AND Auerbach10.

* Obtained through the courtesy of Dr. H. BAUER, National Institutes of Health, Bethescla. Maryland. 
need to do its own standardization although the constants should not vary appreciably from the ones given in Table II. The constants are used to calculate the amounts of the imidazoles in biological material'.

\section{Preparation of biological material}

Tissue. Rat muscle, liver, and brain is frozen and ground in a Wiley mill (40 gauge screen) at the temperature of liquid nitrogen. The powdered material obtained is lyophylized, defatted by extraction with diethyl ether-absolute ethanol $(3: I, V / V)$ for $24 \mathrm{~h}$ in a Soxhlet extractor. A picric acid extract of the dried material is prepared by the procedure of TALLAN et al.12.

Urine. Urine is refrigerated during the collection period. Phenol should not be added as a preservative ${ }^{13}$. The aliquot of the $24 \mathrm{~h}$ specimen to be analyzed is filtered and $6 M \mathrm{HCl}$ added until the $\mathrm{pH}$ is between 2.0 and 2.5 .

Plasma. Plasma is deproteinized and filtered by the method of STEIN AND MOORE 14 .

\section{RESUI,TS AND DISCUSSION}

Standard solution

Fig. 2 shows a typical chromatogram obtained with the stock solution diluted to a concentration of $0.250 \mu$ moles. Imidazolepyruvic acid appears first, approximately $3.5 \mathrm{~h}$ after the buffer gradient flow is started, and is eluted in a broad band. The peak is sharper, of course, as the concentration of the imidazole is increased.
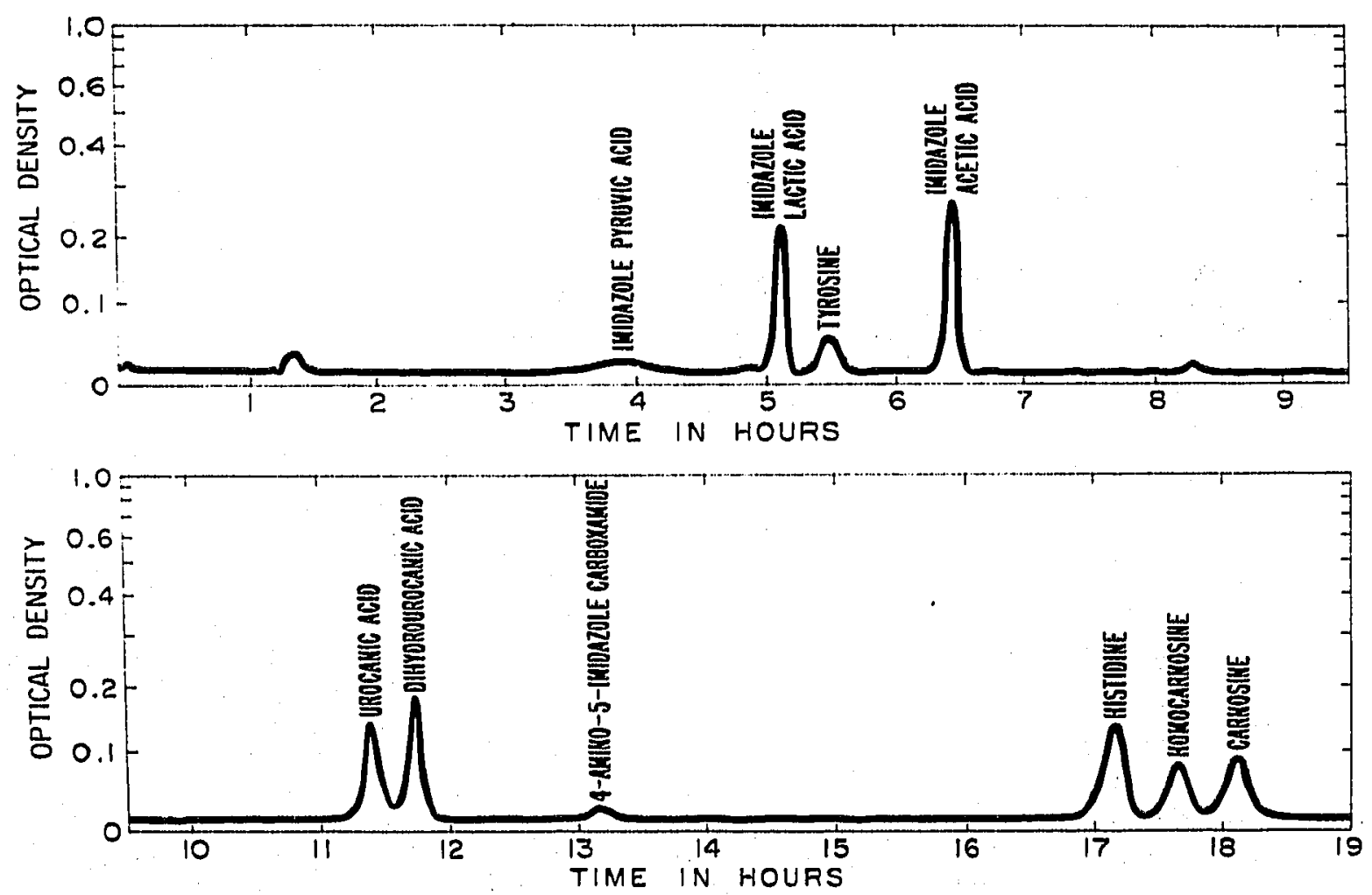

Fig. 2 . Chromatogram of the stanclard solution containing 9 imiclazole compouncls plus tyrosine at a concentration of $0.250 \mu$ moles. 
The other 8 imidazole compounds and tyrosine are eluted in the order shown in Fig. 2 , and give sharp and definite peaks at a concentration of $0.250 \mu$ moles. No overlap of compounds occurs. The precision of the chromatography and the constants obtained for the various imidazole compounds did not vary more than $4 \%$ over a range of concentrations (Table II).

The two small peaks on the chromatogram eluted at approximately I.5 and $8.5 \mathrm{~h}$ after initiation of the buffer gradient flow are unidentified, diazotizable material, and possibly are due to small amounts of impurities contained in one or more of the substances comprising the standard solution.

\section{Biological naterial}

Fig. 3 shows a chromatogram obtained with urine collected from a control male human subject ingesting an ad libitum diet. Imidazolelactic acid, the first diazotizable substance identified in the urine, was eluted approximately $5 \mathrm{~h}$ after initiation of the buffer gradient flow; carnosine, the last to be eluted, appeared approximately $\mathrm{I}_{3} \mathrm{~h}$ later. The imidazole compounds in the urine were eluted in the same order and position, relative to time of buffer gradient flow, as the synthetic imidazole compounds comprising the standard solution (Figs. 2 and 3). Each of the synthetic imidazole compounds added separately to replicate samples of the urine was eluted in a single peak. No unidentified, diazotizable compounds could be detected in the eluate from the chromatographed urine in the time interval between the appearances of imidazolelactic acid and carnosine (Fig. 3).
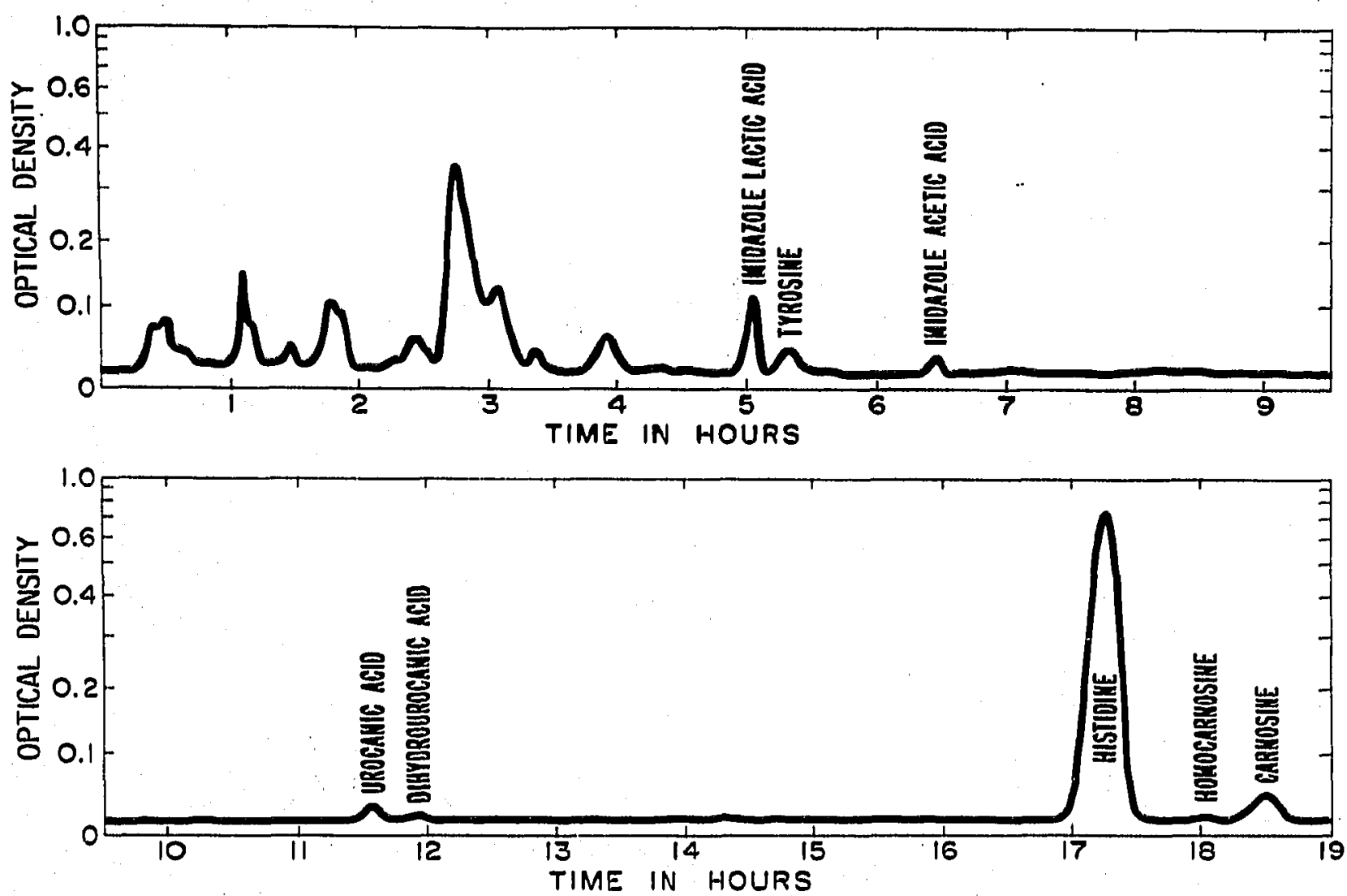

Fig. 3. Chromatogram of urine collected from a control male human subject ingesting an ad libitum diet. 


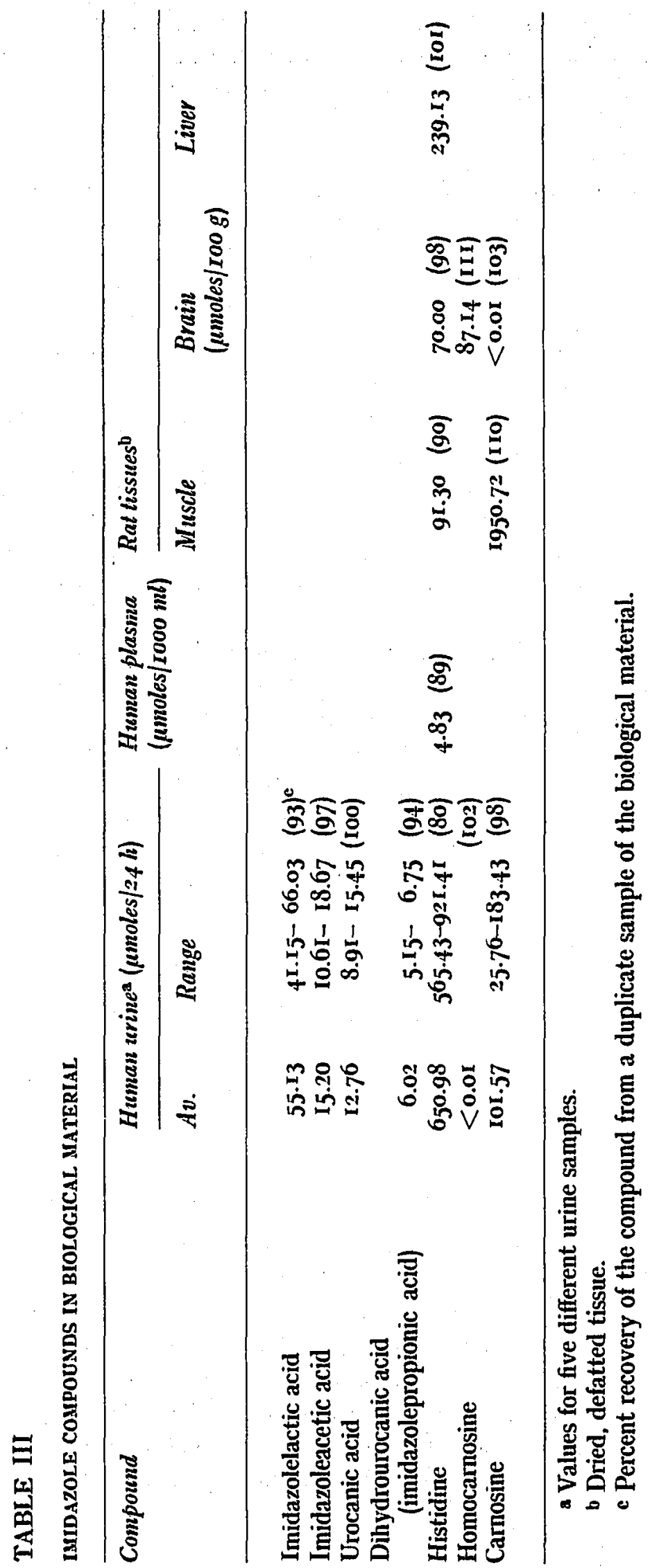


Table III shows the amounts of specific diazotizable imidazole compounds present in a $24 \mathrm{~h}$ collection of human urine, in plasma from a fasting human subject, and in 3 tissues from the rat. The percentage recovery of the various synthetic imidazole compounds added at a concentration of $0.250 \mu$ moles to a replicate aliquot of the biological material, also is given.

Seven diazotizable imidazole compounds were identified in urine from control human subjects. They ranged in amounts from 92I.4I $\mu$ moles of histidine to less than $0.0 x \mu$ moles of homocarnosine $/ 24 h$ (Table III). Imidazolepyruvic acid was not detected in the control urines; however, it was present in large amounts in urine from a patient with histidinemia*, and was separated completely from the other diazotizable substances in the abnormal urine by the automated ion-exchange chromatographic technique.

Recoveries of known amounts of synthetic imidazole compounds added to human urine ranged from 93 to I02 \% (Table III), and are well within the accepted scope for biological fluids. Histidine is an exception; recovery of this compound from urine is low ( $80 \%)$. The cause is not known.

Human plasma contained $4.83 \mu$ moles of histidine/IOo $\mathrm{ml}$; a small amount of diazotizable material eluted at approximately $5.5 \mathrm{~h}$ of buffer gradient flow was identified as tyrosine.

Rat muscle contained histidine and carnosine in calculable amounts. Rat brain contained histidine, homocarnosine and carnosine; the 3 imidazoles are separated completely in a single extract of brain tissue by the ion-exchange chromatographic technique used. Rat liver contained histidine in calculable amounts. Within the working range ( 3.5 to I9 $\mathrm{h}$ of buffer gradient flow) of the method, no other diazotizable substances could be detected in amounts which could be quantitated.

Recovery of added imidazole compounds to plasma and to the different rat tissues ranged from 89 to III \% (Table III).

ACKNOWLEDGEMENT

This study was supported in part by U.S. Public Health Service Grant AM06825-03.

The authors wish to thank Miss MARA E. MARkovs for able technical assistance in the initial phase of this study.

SUMMARY

A quantitative, automated apparatus is described for the simultaneous determination of a number of diazotizable imidazole compounds in the same sample of biological material. Its use in the analysis of urine, plasma and extracts of body tissues is illustrated. In practice, the biological fluid or tissue extract is applied to an ion-exchange column and a buffer gradient of increasing $\mathrm{pH}$ and ionic strength is used to separate the various imidazole compounds. The resulting eluate automatically is made alkaline, diazotized, and the color produced is determined by continuous photometry. The results are plotted automatically on a recording microammeter.

* Unpublished clata. 
Imidazolepyruvic acid, imidazolelactic acid, imidazoleacetic acid, urocanic acid, dihydrourocanic acid (imidazolepropionic acid), 4-amino-5-imidazolecarboxamide, histidine, homocarnosine and carnosine can be separated from each other with no overlapping. The values for each compound, using a solution composed of the pure compounds, can be integrated with a precision of roo $\pm 4 \%$ over a range of concentrations. A complete analysis requires between IS to $20 \mathrm{~h}$.

\section{REFERENCES}

I H. TABOR, Mathods Enzymol., 3 (I957) 623.

2 H. TABOR, Methods Enzymol., 6 (I963) $58 \mathrm{r}$.

3 G. WOLF, P. WU AND W. HECK, J. Biol. Chem., 222 (1956) I59.

4 J. J. Pisano, J. D. Wilson, L. Cohen, D. Abraham and S. Udenfriend, J. Biol. Chem., 236 (I96I) 499.

5 D. Abraham, J. J. Pisano and S. Udenfriend, Alch. Biochem. Biophys., 99 (Ig62) 2 Io.

6 H. Pauly, Z. Physiol. Chem., 42 (1904) 508.

7 D. H. Spackman, W. H. Stein and S. Moore, Anal. Chem., 30 (I958) I rgo.

8 S. Moore, D. I- Spackman and W. H. Stein, Anal. Chem., 30 (1958) II85.

9 P. D. Spotter AND R. C. Baldridge, J. Biol. Chem., 238 (I963) 207 I.

IO R. C. BALDRIDGE AND V. H. AUERBACH, J. Biol. Chem., 239 (I964) I 557.

I I S. Moort AND W. H. Stein, J. Biol. Chem., 2 I I (I954) 893.

I2 H. H. TALLAN, W. H. STEIN AND S. Moore, J. Biol.Chem., 2 I I (1954) 927.

I G. HuNTER, Biochem. J., I6 (I922) 640.

I 4 W. IH. SteIN ANDS. MOORE, J. Biol. Chem., 2 II (I954) 9 I5. 